\title{
The preclinical evaluation of immunocontraceptive vaccines based on canine zona pellucida 3 (cZP3) in a mouse model
}

Ying Wang, Yijie Li, Beibei Zhang and Fuchun Zhang*

\begin{abstract}
Background: Stray dogs are the reservoirs and carriers of rabies and are definitive hosts of echinococcosis. To control the overpopulation of stray dogs, zona pellucida 3 (ZP3), a primary receptor for sperm, is a potential antigen for developing contraceptive vaccines.

To enhance the immune responses and contraceptive effects of canine ZP3 (CZP3), dog gonadotropin-releasing hormone $(\mathrm{GnRH})$ and a T cell epitope of chicken ovalbumin (OVA) were selected to construct two fusion proteins with CZP3, ovalbumin-GnRH-ZP3 (OGZ) and ovalbumin-ZP3 (OZ), and their contraceptive effects were evaluated in mice.
\end{abstract}

Methods: The synthesized DNA sequences of $O G Z$ and $O Z$ were cloned into plasmid pET-28a respectively. The fusion proteins OGZ and OZ were identified by SDS-PAGE and Western blot. Mice were immunized with OGZ, OZ and cZP3, and the infertility rates were monitored. Mice immunized with mouse ZP3 (mZP3) or adjuvant alone were used as positive control and negative control, respectively. CZP3- and GnRH-specific antibodies (Abs) were detected by ELISA. The bindings of the Abs to oocytes were detected by indirect immunofluorescence assay. The paraffin sections of mice ovaries were observed under microscope for analyzing pathological characteristics.

Results: SDS-PAGE and Western blot analyses showed that the two fusion proteins OGZ and OZ were correctly expressed. ELISA results showed that OGZ vaccine induced both cZP3- and GnRH-specific Abs, and OZ vaccine induced CZP3-specific Ab, which lasted for up to 168 days. The levels of follicle stimulating hormone (FSH) and estradiol (E2) in sera were significantly decreased in OGZ immunized mice. Indirect immunofluorescence results showed that Abs induced by CZP3 and mZP3 could bind to the mouse ZP and dog ZP each other. Compared with the adjuvant group, all vaccine immunized groups significantly decreased the fertility rate and mean litter size. Interestingly, the fertility rate in OGZ-immunized group is the lowest, and only 1 mouse out of 10 mice is fertile. Histological analysis of murine ovarian sections indicated that most of the infertile mice in the immunized groups lacked mature follicles as well as accompanied by inflammatory infiltration. Meanwhile, immunization with OGZ decreased the number of corpora lutea in the infertile mice.

Conclusions: The fusion protein OGZ resulted in the lowest fertility rate and the least mean litter size in the immunized mice. OGZ might be a promising antigen for developing a new contraceptive vaccine for stray dog controlling.

Keywords: Dog, Zona pellucida 3, GnRH, Fusion protein, Contraceptive vaccine

\footnotetext{
* Correspondence: fuchunzhangxju@126.com

Xinjiang Key Laboratory of Biological Resources and Genetic Engineering,

College of Life Science and Technology, Xinjiang University, 666, Shengli

Road, Urumqi 830046, China
}

(c) The Author(s). 2018 Open Access This article is distributed under the terms of the Creative Commons Attribution 4.0 International License (http://creativecommons.org/licenses/by/4.0/), which permits unrestricted use, distribution, and reproduction in any medium, provided you give appropriate credit to the original author(s) and the source, provide a link to the Creative Commons license, and indicate if changes were made. The Creative Commons Public Domain Dedication waiver (http://creativecommons.org/publicdomain/zero/1.0/) applies to the data made available in this article, unless otherwise stated. 


\section{Background}

Nowadays, the overpopulation of stray dogs has seriously affected peoples' daily lives as well as city's environmental sanitation. Stray dogs in Xinjiang, China, are the reservoirs and carriers of rabies, and they are definitive hosts of echinococcosis. Therefore, it is urgent to develop effective contraceptive vaccines to control stray dog's population. Zona pellucida 3 (ZP3), as the primary receptor of sperm on egg cell and an inducer of the acrosome reaction, plays a key role during fertilization [1-4]. Extensive studies have demonstrated that contraceptive vaccines based on ZP3 can limit the population of mice [5-7], koalas [8], gray kangaroos [9], and rabbits [10]. Recombinant canine ZP3 (cZP3) can also induce infertility in female dogs [11]. In this study, cZP3 of 35 350aa containing the major B-cell epitopes was selected as the basic antigen for immunocontraception.

To enhance the contraceptive efficacy of cZP3, canine gonadotropin-releasing hormone $(\mathrm{GnRH})$ was selected as another antigen. GnRH plays an important role in vertebrate fertilization. It is a decapeptide produced by hypothalamus. Immunization with $\mathrm{GnRH}$ can produce contraceptive effects in both males and females [12-14]. Several commercial GnRH-based contraceptive vaccines have been developed, and these vaccines appear to have different functions in different animal species [15-17]. Thus, canine GnRH was selected as the second antigen for preparing a fusion protein vaccine. In addition, a T-cell epitope (QAVHAAHAEINE) of chicken ovalbumin (OVA) was added to the $\mathrm{N}$-terminal of the fusion protein to further enhance the immune responses [18].

In this study, we chose cZP3 as the basic antigen for constructing two fusion proteins that encompassed a $\mathrm{T}$ cell epitope of OVA and, or GnRH. The contraceptive efficacy of the two fusion proteins were evaluated in female mice. The related $\mathrm{Ab}$ levels and the binding of Abs on ZP3 of oocytes were conducted to explain the mechanisms underlying the contraceptive effect.

\section{Methods}

Animals

All animal experiments in this study were approved by the Animal Ethics Committee of Xinjiang University. Treatment and care of animals were conducted strictly according to the guidelines, and all efforts were made to minimize damages to the animals. All mice were maintained under constant room temperature $\left(21 \pm 2^{\circ} \mathrm{C}\right)$ with a photoperiod of $\mathrm{D} 12$ : 12. Mice had free access to food and water. No mice died during the experiments.

\section{Construction, expression and purification of the fusion proteins}

Two recombinant fragments $O G Z$ and $O Z$ were constructed. For $O G Z$, canine GnRH (G) and cZP3 (23
350 aa) (Z) nucleotide sequences were retrieved from GenBank (XP_850859.2 and NM 001003224.1). A T-cell epitope of chicken ovalbumin (O) was added to the $5^{\prime}$-end of the recombinant fragment. A flexible linker (Gly-Gly-GlyGly-Ser) (GGGS) was inserted to separate each component in the fusion protein (Fig. 1a). OZ recombinant fragment was constructed same as OGZ except for missing the GnRH and the second GGGS (Fig. 1a). The synthesized DNA sequences were codon-optimized for $E$. coli expression, and the expressed fusion proteins were named as OGZ and OZ, respectively. The nucleic acid fragments of $O G Z$ and $O Z$, were digested with $E c o \mathrm{R} \mathrm{I}$ and $B a m \mathrm{H} \mathrm{I}$, and cloned into pET28a vector respectively. The recombinant plasmids pET28a-OGZ and pET28a-OZ were transformed into E. coli BL21 (DE3) cells respectively. The expressional conditions were optimized by testing different combination of factors, including isopropyl $\beta$-D-1-thiogalactopyranoside (IPTG) concentration $(0.1,0.3,0.5,0.8,1,1.5$ and $2 \mathrm{mmol} / \mathrm{L})$, induction time $(4 \mathrm{~h}, 6 \mathrm{~h}$ and $8 \mathrm{~h})$ and temperature $\left(25^{\circ} \mathrm{C}, 30{ }^{\circ} \mathrm{C}\right.$ and $37^{\circ} \mathrm{C}$ ). Finally, the optimal induction conditions in $1 \mathrm{~L}$ LB medium for OGZ or OZ expression was as follows: $10 \mathrm{~mL}$ overnight culture was inoculated into $1 \mathrm{~L} \mathrm{LB}$ medium and cultured at $37{ }^{\circ} \mathrm{C}$ with shaking at $250 \mathrm{r} / \mathrm{min}$. When $\mathrm{OD}_{600}$ reached between 0.4 0.6, $1 \mathrm{mM}$ IPTG was added into the culture. The culture was continually incubated at $37^{\circ} \mathrm{C}$ for $4 \mathrm{~h}$. Cell pellets were harvested by centrifugation at $5000 \mathrm{r} / \mathrm{min}$ for $15 \mathrm{~min}$ and washed once with phosphate buffered saline (PBS). Then, the pellets were resuspended in PBS $(100 \mathrm{mg} / 2 \mathrm{~mL}$, containing $20 \mu \mathrm{L}$ protease inhibitor cocktail) and sonicated in an ice bath for $20 \mathrm{~min}$ at $5 \mathrm{~s}$ intervals. The cell lysate was harvested by centrifugation at $10000 \mathrm{r} / \mathrm{min}$ for $15 \mathrm{~min}$, and the pellets were resuspended in $20 \mathrm{~mL}$ binding buffer $(20 \mathrm{mM}$ Tris- $\mathrm{HCl}, \mathrm{pH} 7.9$, containing $6 \mathrm{M}$ urea, $0.5 \mathrm{M} \mathrm{NaCl}$, and $5 \mathrm{mM}$ imidazole). After spinning at $10000 \mathrm{r} / \mathrm{min}$ for $20 \mathrm{~min}$, the filtrated supernatant was passed through a nickel-affinity chromatography column three times and washed 20 times with a column volume of binding buffer. The fusion proteins were eluted by elution buffer (500 $\mathrm{mM}$ imidazole). After ultrafiltration, protein concentrations were determined using a $\mathrm{BCA}$ Protein Assay Kit (Thermo).

\section{Western blot analysis of the fusion proteins OGZ and OZ}

The antisera against cZP3 (23 350 aa) and GnRH were raised respectively by one subcutaneous and two intraperitoneal injections in female mice.

The transformed $E$. coli cells were induced with IPTG to express OGZ and OZ respectively. The whole cells were collected by centrifugation at $10000 \mathrm{r} / \mathrm{min}$ for $1 \mathrm{~min}$ and washed once with PBS. The pellets were dissolved in SDS-PAGE loading buffer and heated at $100{ }^{\circ} \mathrm{C}$ for $5 \mathrm{~min}$. The samples were then separated on a $12 \%$ SDS-PAGE gel and transferred onto PVDF membranes separately. The membranes were blocked with $5 \%$ skim milk powder 
a

\begin{tabular}{|l|l|l|l|l|l|}
\hline OVA T cell epitope & GGGS & GnRH & GGGS & CZP3c(23-350) & OG2 \\
\hline
\end{tabular}

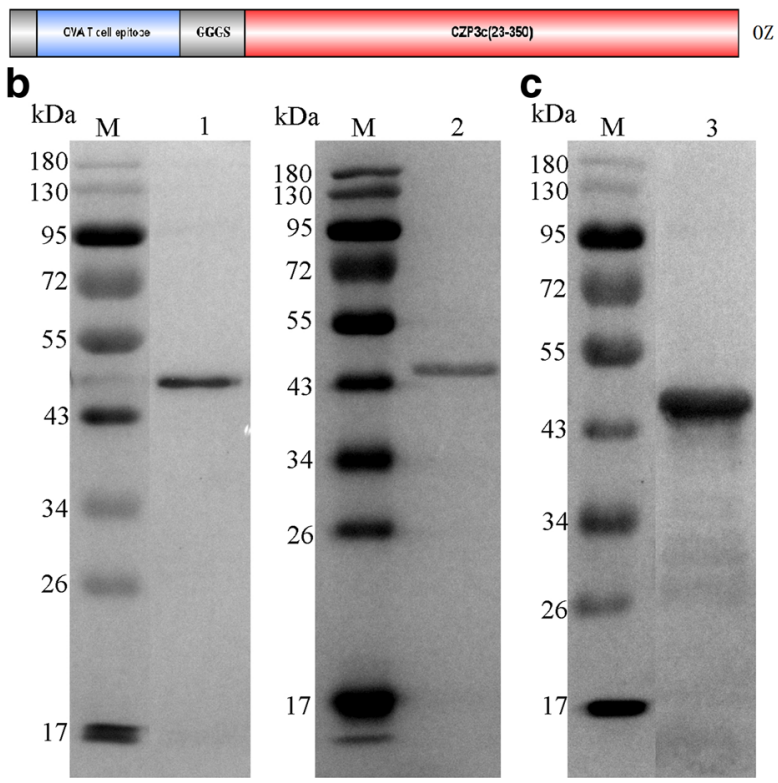

Fig. 1 Schematic representation and Western blot analysis of the fusion proteins OGZ and OZ. a. The main components of OGZ were $T$ cell epitope of OVA, GnRH and cZP3. The main components of OZ were T cell epitope of OVA and cZP3. A flexible linker (GGGS) was inserted in between the components. b. OGZ and OZ reacted with antibodies (Abs) against CPZ3. Lane 1: OGZ, lane 2: OZ. C. OGZ reacted with Abs against GnRH. Lane 3: OGZ. Lane M: protein molecular weight markers

dissolved in 0.5\% Tween-20 in TBS pH 7.9 (TBST) at $4{ }^{\circ} \mathrm{C}$ overnight. The membranes were then probed with different anti-sera. For OGZ and OZ, the membranes were probed with Abs against cZP3. OGZ was also probed with Abs against GnRH. After incubation at $4{ }^{\circ} \mathrm{C}$ for $2 \mathrm{~h}$, the membranes were washed with TBST three times. Horseradish (HRP)-conjugated goat anti-mouse IgG was used as a second $\mathrm{Ab}$. Color was developed with 3, 3'-diaminobenzidine (DAB). All reactions were terminated by adding distilled water.

\section{Mouse immunization}

Fifty female BALB/c mice (6 8 weeks old) were purchased from Xinjiang Medical University and were randomly divided into five groups $(n=10)$. Immunization with OGZ, OZ and cZP3 (23 350 aa) was designated as the antigen-specific groups. Immunization with mouse ZP3(mZP3, 21 361 aa) was designated as positive control. cZP3 and mZP3 proteins were previously expressed and purified in our laboratory. Freund's adjuvant injection was set as a negative control.

After the protein was emulsified with Freund's complete adjuvant, each mouse received $25 \mu \mathrm{g}$ protein subcutaneously. The same amount of protein was given intraperitoneally as a booster dose on day 21 and 42 after administration of the first immunization. Serum samples were collected from the retro-orbital on day $14,35,56$, and 168 after the first immunization. $70 \mu \mathrm{L}$ sera were collected from each mouse, and were stored at $-80{ }^{\circ} \mathrm{C}$ for later use.

\section{Detection of the abs levels by enzyme linked immunosorbent assay (ELISA)}

We detected the Ab levels of ZP3 and GnRH using ELISA. A ninety-six-well plate was coated with $100 \mu \mathrm{L}$ ZP3 $(4 \mu \mathrm{g} / \mathrm{mL})$ and incubated at $4{ }^{\circ} \mathrm{C}$ overnight. The plate was blocked with blocking buffer (5\% skim milk powder in PBST) at $37^{\circ} \mathrm{C}$ for $1 \mathrm{~h}$. After washing three times, the plate was incubated with serum $(100 \mu \mathrm{L}$ per well) diluted at 1:1000 in blocking buffer at $37^{\circ} \mathrm{C}$ for $1 \mathrm{~h}$. Then, the plate was incubated with the second $\mathrm{Ab}$, HRP-conjugated goat anti-mouse IgG at a dilution of 1 : 1000 , at $37^{\circ} \mathrm{C}$ for $1 \mathrm{~h}$. TMB substrate solution (Thermo) $(50 \mu \mathrm{l}$ per well) was used for color development. After $15 \mathrm{~min}$, the reaction was terminated by adding the same volume of $0.2 \mathrm{M} \mathrm{H}_{2} \mathrm{SO}_{4}$. Absorbance values were read at $\mathrm{OD}_{450} \mathrm{~nm}$.

The GnRH Ab levels were detected as described above. The optimal coating concentration of $\mathrm{GnRH}$ was $15 \mu \mathrm{g} / \mathrm{mL}$ and the working concentration of the serum samples was 1:100 dilution as determined by chessboard assay. 
Determination of the levels of FSH and E2 in the sera of OGZ immunized mice by ELISA

The levels of FSH and E2 in the mice sera of adjuvant and OGZ groups were determined respectively by sandwich and competitive ELISA according to the manufacturer's instructions (Elabscience, Wuhan, China). Serum samples were collected on day 14, 35 and 56 after the first immunization. The assay sensitivity was $1.56 \sim 100 \mathrm{ng} / \mathrm{mL}$ and $40 \sim 1400 \mathrm{pg} / \mathrm{mL}$, respectively. The intra- and interassay of the variations for FSH and E2 was 10 and 15\%, respectively.

\section{Indirect immunofluorescence of mouse oocytes}

Five 6-week-old female BALB/c mice were stimulated by intramuscular injection with $12 \mathrm{IU}$ of pregnant mare serum gonadotrophin (PMSG, Ningbo Sansheng Pharamceutical, China). $46 \mathrm{~h}$ later, these mice were injected intramuscularly with 12 IU human chorionic gonadotropin (hCG, Ningbo SanSheng Pharamecutical, China). All the mice were sacrificed after $13 \mathrm{~h}$ of the injection, and the cumulus-oocyte complexes (COCs) were collected from the mice ampulla. After incubation with hyaluronidase $(50 \mu \mathrm{g} / \mathrm{mL})$ for $5 \mathrm{~min}$, the denuded oocytes were obtained. The oocytes were blocked with blocking buffer (5\% BSA in PBS) at $37^{\circ} \mathrm{C}$ for $1 \mathrm{~h}$, and then were transferred into the freshly diluted serum droplets (1:50) for $1 \mathrm{~h}$. After the oocytes were washed several times with PBS, fluorescein isothiocyanate (FITC)-conjugated rabbit anti mouse IgG (1:200) was added, then the oocytes were incubated at $37{ }^{\circ} \mathrm{C}$ for 30 min. Finally, the oocytes were washed with PBS and observed under fluorescence microscope.

\section{Indirect immunofluorescence of dog ovarian sections}

For detecting whether the antisera of the OGZ- and OZ- immunized mice could bind to dog oocytes, we performed surgery and collected four ovaries from two Beagles. The ovaries were immediately fixed in $4 \%$ paraformaldehyde and kept at $4{ }^{\circ} \mathrm{C}$ for at least $24 \mathrm{~h}$, and then were made into paraffin sections. The sections were blocked with PBS containing 10\% normal rabbit sera at $37{ }^{\circ} \mathrm{C}$ for $1 \mathrm{~h}$. Serum samples (from the mice of adjuvant, OGZ, OZ, mZP3 and cZP3 injection) were diluted with blocking buffer (1:50), and were added onto the sections, respectively, and kept at $4{ }^{\circ} \mathrm{C}$ overnight. The diluted FITC conjugated rabbit anti mouse IgG (1:200 in blocking buffer) was added as a second Ab. After washing, the paraffin sections were observed under fluorescence microscope.

\section{Evaluation of the contraceptive effects in vivo}

On day 56 after the primary immunization, mice in each group were divided into five cages (two mice per cage) and a healthy male mouse was put into each cage. The male mice were rotated in the cages every day. After 3 weeks, the male mouse was removed from the cage, and the litter size of each female mouse was counted. On day 168 , the mating test was repeated.

\section{Histological analysis}

On day 210 after the first immunization, all of the mice were sacrificed. The ovaries from each mouse was obtained and fixed in $4 \%$ paraformaldehyde at $4{ }^{\circ} \mathrm{C}$. After embedded with paraffin, the ovaries were cut into two consecutive sections at $5 \mu \mathrm{m}$ thickness. The sections were stained with hematoxylin and eosin, and observed under microscope. Histopathological changes of the ovaries were graded 0 to 4 as previously described [19].

\section{Statistical analysis}

The Abs levels for FSH, E2 and GnRH were analyzed by one-way analysis of variance (one-way ANOVA) and Tukey's multiple comparison test. The Ab levels of ZP3 during the immunization were analyzed by two-way ANOVA. The correlation between the sera FSH concentration and the $\mathrm{Ab}$ levels of $\mathrm{GnRH}$ was analyzed using Pearson's correlarion coefficient. For analysis of the difference in mean litter size among each group, the data was firstly converted into square root of $x+1$, then analyzed by one-way ANOVA and Tukey's multiple comparison test. The Ab levels and the mean litter size were presented as mean \pm SEM. $P<0.05$ was considered as significant.

\section{Results \\ Purification and detection of the fusion proteins OGZ and $\mathrm{OZ}$}

Fusion protein OGZ was combined with canine GnRH (G), cZP3 (Z, 23 350 aa) and a T-cell epitope of chicken ovalbumin $(\mathrm{O})$. Fusion protein $\mathrm{OZ}$ was combined with cZP3 (Z, 23 350 aa) and chicken OVA (O) (Fig. 1a). After these two proteins were expressed in E.coli by IPTG induction, and after proteins purification, the fusion protein OGZ and OZ showed a major band at $46 \mathrm{kDa}$ and $44 \mathrm{kDa}$ on SDS-PAGE gel respectively as expected (figure not shown). Western blot results confirmed these specific bands accordingly. Both OGZ and OZ could bind to the Abs against cZP3 (Fig. 1b). Besides, OGZ also bound to Abs against $\mathrm{GnRH}$ (Fig. 1c).

\section{Fusion proteins induced high levels of abs against ZP3}

From day 14 to day 56 after the first immunization the levels of the Ab against ZP3 in all proteins immunized mice were significantly higher than the adjuvant control group. The increase of the Ab levels was in a linear way with the time prolonging. On day 168 the Ab levels decreased greatly but still kept $5 \sim 10$ fold of the adjuvant control (Fig. 2a). There was no significant difference among these protein groups. In addition, OGZ group could also generate high levels of $\mathrm{Ab}$ against $\mathrm{GnRH}$ and the levels also last 

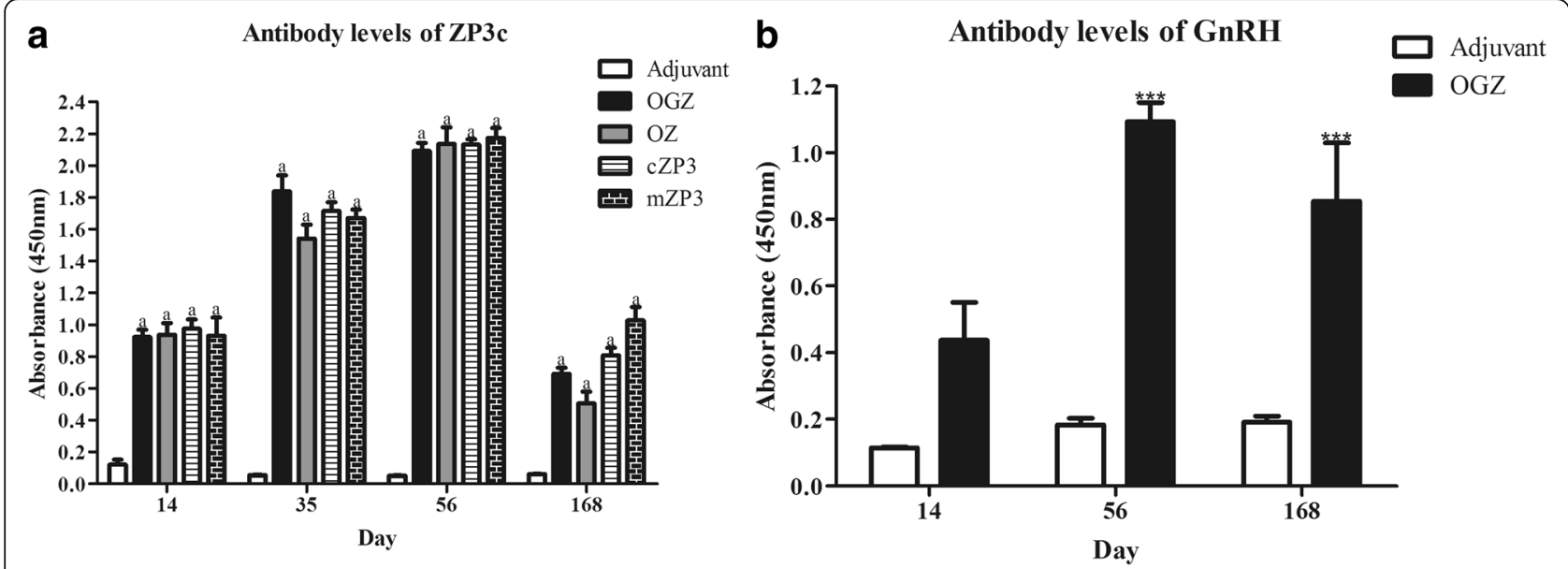

Fig. 2 Antibody levels of ZP3 and GnRH in serum. Sera were collected from the mice on day 0, 14, 35, 56 and 168 after the 1st immunization. a. Ab levels of ZP3. All the serum samples were diluted (1:1000) with PBST containing 5\% skim milk. HRP-conjugated goat anti-mouse lgG Ab (1:1000) was used as the second Ab. b. Ab levels of GnRH. Serum samples were collected from the mice on day 14,56 and 168 at 1:100 dilution. Data are shown as mean \pm SEM. ${ }^{* * *} P<0.001$

for 168 days (Fig. 2b). However, the levels of Ab against GnRH were not as high as that of ZP3.

\section{Sera FSH and E2 levels were significantly decreased in OGZ group}

The sera FSH and E2 levels in the OGZ group showed a gradual decline (Fig. 3a, b) after immunization, and for FSH it was almost undetectable on day 56 after the first immunization. The FSH concentration in the sera of OGZ group was negatively correlated with the Ab levels of $\mathrm{GnRH}$ (Fig. 3c) with a Pearson's correlation coefficient of -0.6403 .

\section{Abs against fusion proteins could bind to the ZP matrix of mouse and dog}

Indirect immunofluorescence assay of mice oocytes showed that the Abs against ZP3 in each vaccine immunization group could specifically bind to the ZP matrix of mice (Fig. 4a). Meanwhile the results of indirect immunofluorescence assay to dog ovarian sections suggested the Abs against ZP3 in each vaccine group could react with the $\operatorname{dog} \mathrm{ZP}$ matrix, but not with other cells in ovaries (Fig. 4b).

\section{Immunization with OGZ and OZ both caused a decline in mice fertility}

To detect the contraceptive effects of the fusion proteins, the OGZ and OZ immunized female mice were mated respectively with male mice for 3 weeks on day 56 after the first immunization. The results showed that both the fertility rate and litter size in OGZ group and OZ group decreased significantly compared to the adjuvant group, so did the mZP3 and cZP3 groups. The fertility rate decreased from $100 \%$ in the adjuvant group to $10 \%$ in OGZ group, $40 \%$ in mZP3 group and $50 \%$ in cZP3 and OZ groups (Table 1).

To detect how long the contraceptive efficacy of $\mathrm{OGZ}$ and $\mathrm{OZ}$ vaccines could last, the mating test was re-conducted on day 168 . The results showed that the

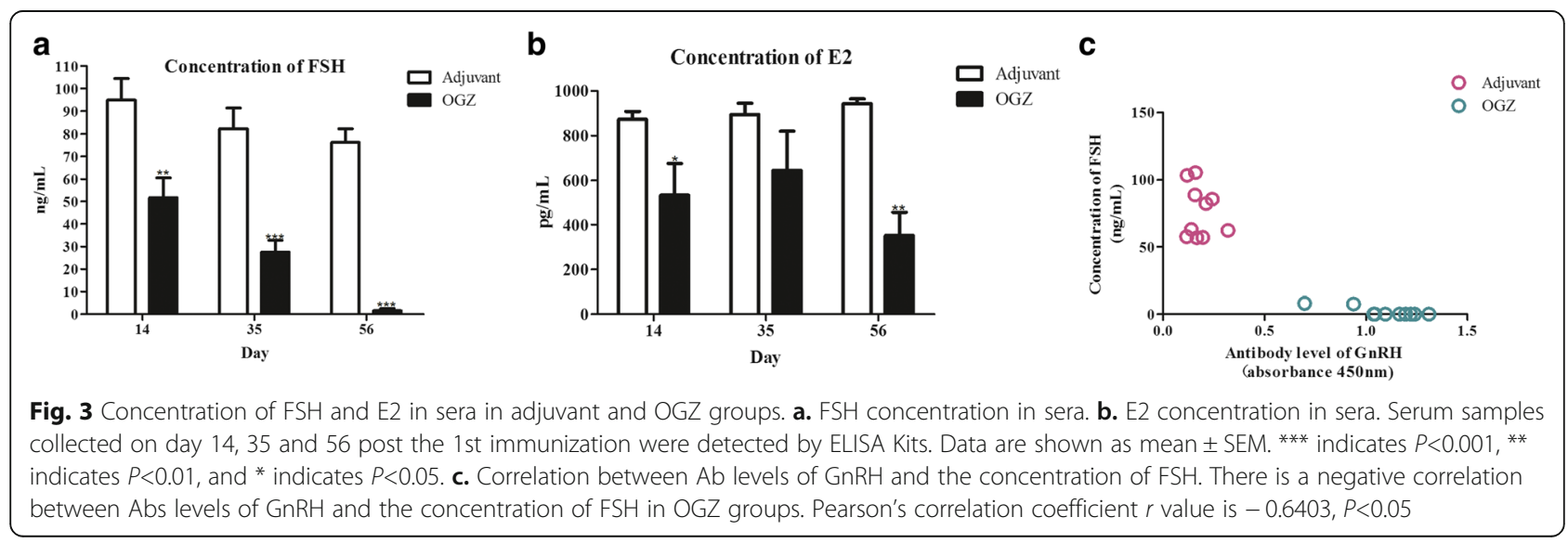




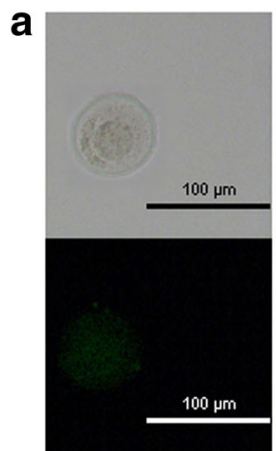

a

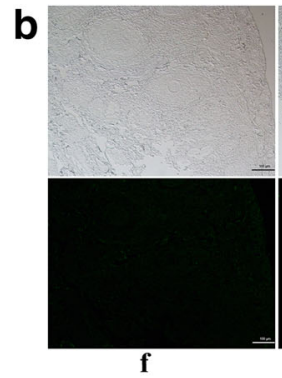

f

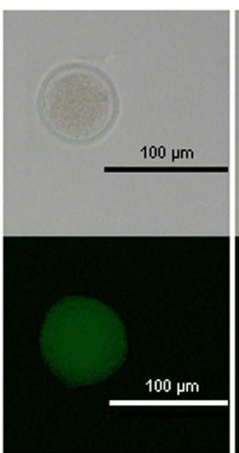

b

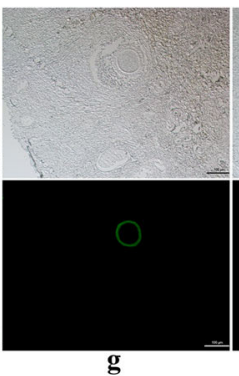

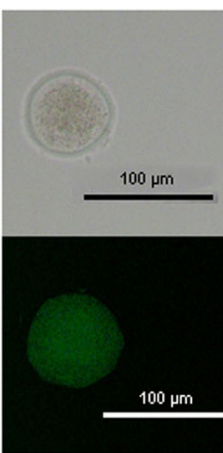

c
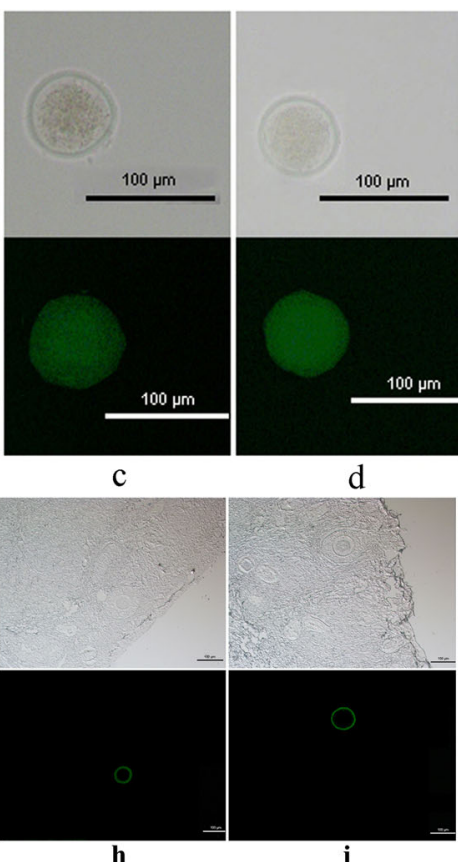

d

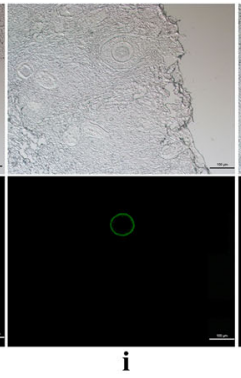

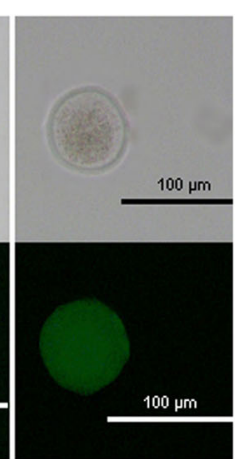

e

Fig. 4 Abs against ZP3 could react with mouse and dog ZP in the indirect immnofluorescence assay. $\mathbf{a}$. Abs against ZP3 react with mouse oocytes. $\mathbf{a}, \mathbf{b}$, c, $\mathbf{d}$ and $\mathbf{e}$ represent adjuvant, OGZ, OZ, CZP3 and mZP3, respectively. $\mathbf{b}$. Abs against ZP3 reacted with sections of dog ovaries. $\mathbf{f}, \mathbf{g}, \mathbf{h}, \mathbf{i}$ and $\mathbf{j}$ represent the adjuvant, OGZ, OZ, CZP3 and mZP3, respectively. The top panel is in bright field, the bottom panel is in fluorescent field

fertility rate and litter size in each group increased slightly compared to the first mating, but still kept a significant decrease compared to the adjuvant group. The fertility rate decreased from $100 \%$ in the adjuvant group to $10 \%$ in the OGZ group and $50 \%$ in OZ, cZP3 and mZP3 groups (Table 2).

The average litter size in OZ group was 2.3, similar to the groups of mZP3 which was 2 and cZP3 which was 2.2, and all of them were very significantly lower than the

Table 1 Contraceptive effects of the recombinant proteins in the first mating test

\begin{tabular}{lllll}
\hline Antigen & Fertility rate (\%) & Mean litter size & Average Abs levels & $P^{c}$ \\
\hline Adjuvant & $100 \%(10 / 10)$ & $7 \pm 0.516$ & $0.050 \pm 0.004^{\mathrm{d}}$ & \\
& & & $0.183 \pm 0.02^{\mathrm{e}}$ & \\
OGZ & $10 \%(1 / 10)$ & $0.4 \pm 0.4$ & $2.092 \pm 0.162^{\mathrm{d}}$ & $* * * *$ \\
& & & $1.095 \pm 0.056^{\mathrm{e}}$ & \\
OZ & $50 \%(5 / 10)$ & $2.3 \pm 0.883$ & $2.138 \pm 0.334^{\mathrm{d}}$ & $* * *$ \\
cZP3 & $50 \%(5 / 10)$ & $2.2 \pm 0.772$ & $2.134 \pm 0.103^{\mathrm{d}}$ & $* *$ \\
mZP3 & $40 \%(4 / 10)$ & $2 \pm 0.907$ & $2.215 \pm 0.156^{\mathrm{d}}$ & $* * *$ \\
\hline
\end{tabular}

${ }^{a}$ Fertility rate: number of the fertile mice/total number of the mated mice in each group

${ }^{\mathrm{b}}$ Mean litter size of mice: total number of pups in each group/total number of the mated mice in each group

${ }^{c} M e a n$ litter size in each group vs adjuvant group;; represents $P<0.05$; ** represents $P<0.01$; *** represents $P<0.005$

${ }^{\mathrm{d}}$ Average Abs levels of cZP3

${ }^{\mathrm{e}}$ Average Abs levels of $\mathrm{GnRH}$ adjuvant group which was 7 (Table 1). The OGZ group had the least average litter size of 0.4 (out of 10 mice only 1 produced 4 pubs). The results in the second mating test showed similar effects (Table 2). These results suggested that these protein vaccines effectively decreased the litter size of the immunized mice, and OZ, cZP3 and mZP3 had similar moderate effect, while OGZ had very strong effect.

The scatter diagrams about the Ab levels of ZP3 and the litter size in each mouse (Fig. 5) showed that all of the

Table 2 Contraceptive effects of the recombinant proteins in the second mating test

\begin{tabular}{|c|c|c|c|c|}
\hline Antigen & Fertility rate (\%) ${ }^{a}$ & Mean litter size ${ }^{b}$ & Average Abs levels & $P^{c}$ \\
\hline \multirow[t]{2}{*}{ Adjuvant } & $100 \%(10 / 10)$ & $6.1 \pm 0.924$ & $0.058 \pm 0.003^{d}$ & \\
\hline & & & $0.191 \pm 0.018^{e}$ & \\
\hline \multirow[t]{2}{*}{ OGZ } & $10 \%(1 / 10)$ & $0.2 \pm 0.2$ & $0.691 \pm 0.039^{d}$ & $* * *$ \\
\hline & & & $0.854 \pm 0.176^{e}$ & \\
\hline $\mathrm{OZ}$ & $50 \%(5 / 10)$ & $2.5 \pm 0.86$ & $0.506 \pm 0.073^{d}$ & * \\
\hline CZP3 & $50 \%(5 / 10)$ & $2.6 \pm 0.884$ & $0.808 \pm 0.047^{d}$ & $*$ \\
\hline mZP3 & $50 \%(5 / 10)$ & $2.7 \pm 0.920$ & $1.028 \pm 0.084^{d}$ & $*$ \\
\hline
\end{tabular}

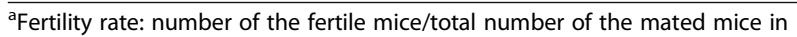
each group

${ }^{b}$ Mean litter size of mice: total number of the pups in each group/total number of the mated mice in each group

${ }^{c}$ Mean litter size in each group vs adjuvant group; represents $P<0.05$; ${ }^{* *}$ represents $P<0.01 ; * * *$ represents $P<0.005$

${ }^{\mathrm{d}}$ Average Abs levels of $\mathrm{CZP} 3$

${ }^{\mathrm{e}}$ Average Abs levels of $\mathrm{GnRH}$ 
mice in the protein groups had higher Ab levels than the adjuvant control, and the litter size was smaller than the adjuvant (Table 1 and Table 2). However, the difference in the litter size among the individuals in each group was great, for OZ, cZP3 and mZP3 groups, the range were 6 , suggesting that random factors had influence on a mouse's litter size apart from the main factor of the contraceptive vaccine. This situation was even evidence in the adjuvant group (Fig. 5), the range was 11. Due to the data severely deviated from normal distribution, Pearson's correlation analysis were not applicable.

\section{Immunization with $\mathrm{OGZ}$ and $\mathrm{OZ}$ led to pathological changes in mice ovaries}

To investigate whether immunization with the fusion proteins could affect mice ovarian morphology, the mice ovaries were collected, and sections were made for observation. We found that, compared with the adjuvant group, most of the infertile mice immunized with protein vaccines had abnormal follicular development, which led to immature follicles. In additon, these ovaries were also accompanied by inflammatory cell infiltration in the atretic follicles and/or the growing and mature follicles. The number of corpora lutea in the infertile mice receiving OGZ also decreased. Most of the fertile mice in these protein immunization groups showed no significant changes in the number of corpora lutea (Fig. 6).

\section{Discussion}

In face of the overpopulation of stray dogs, developing a safe and effective contraceptive vaccine is in need. ZP3, due to the vital function in the fertilization process, is considered as a promising target for such a vaccine. In order to induce a stronger immune response, two recombinant fragments $O G Z$ and $O Z$ were constructed. The fusion proteins OGZ and OZ were correctly expressed in E.coli.

Both of the mature fragment of mZP3 and cZP3 induced strong immune responses in female mice and lead to infertility as expected. OGZ and $\mathrm{OZ}$ also induced strong immune responses, there were no significant differences in the anti-ZP3 Ab levels among the protein immunization groups. Compared to cZP3, mZP3 encompassed all the epitopes on mice ZP matrix, however, it did not elicit the highest Ab level as predicted (Fig. 2a). This is probably because cZP3 has stronger immunogenicity than mZP3 to mouse and stimulated stronger immune responses [20]. This result suggested that in developing contraceptive vaccines for controlling mammalians heterologous ZP3 might be more prospective. Additionally, the anti-GnRH $\mathrm{Ab}$ level was lower than that of anti-ZP3 (Fig. 2b), and this was probably due to the differences in the coating antigen. The Ab levels detected by ELISA with fusion proteins as coating antigens are usually higher than synthetic peptides as coating antigens, and this difference is similar to the results of previous studies [21, 22].

The protein vaccines showed significant contraceptive effects on the immunized female mice. Both the fertility rate and litter size decreased significantly in comparing with the adjuvant group. The effect of OGZ was profound, in the first mating test, 9 out of the 10 mice gave no birth, the only fertilized one only produced 4 pubs which was lower than the average litter size which was $2 \sim 2.3$ in the other ZP3 protein groups. These results suggested that OGZ vaccine not only blocked ZP3 but also blocked $\mathrm{GnRH}$, thus led to the highest infertility rate $(9 / 10)$ than OZ(5/10), cZP3(5/10) and mZP3(4/10).

The Abs against GnRH bind to GnRH to prevent $\mathrm{GnRH}$ from interacting with the receptors, which, in turn, disturb the hypothalamic-pituitray-gonad axis and inhibit downstream hormonal activities, such as the secretion of FSH and E2 [23, 24]. FSH stimulates the production of E2, and a decrease in FSH concentration could suppress the synthesis of E2. In this study, Abs against $\mathrm{GnRH}$ in the female mice were adequate for interacting with $\mathrm{GnRH}$ and resulting in the decrease of E2 concentration. Compared to adjuvant, the sera FSH and E2 levels in OGZ group were remarkably reduced (Fig. 3a, b). These results were similar to other studies in which immunization with $\mathrm{GnRH}$ caused a significant
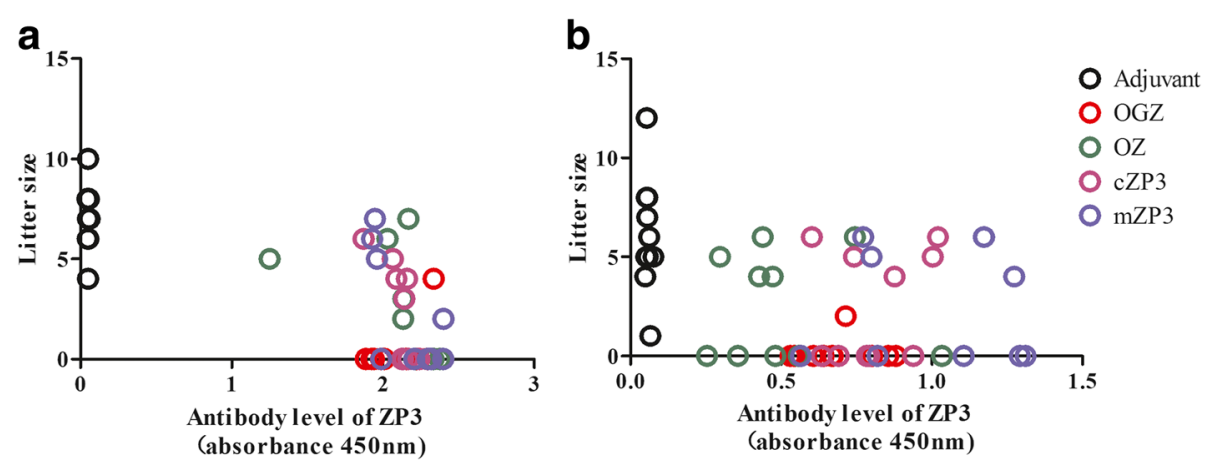

Fig. 5 Scatter diagram of the antibody levels of CZP3 in each mouse and the litter size of each mouse after the first mating (a) and the second mating (b) 

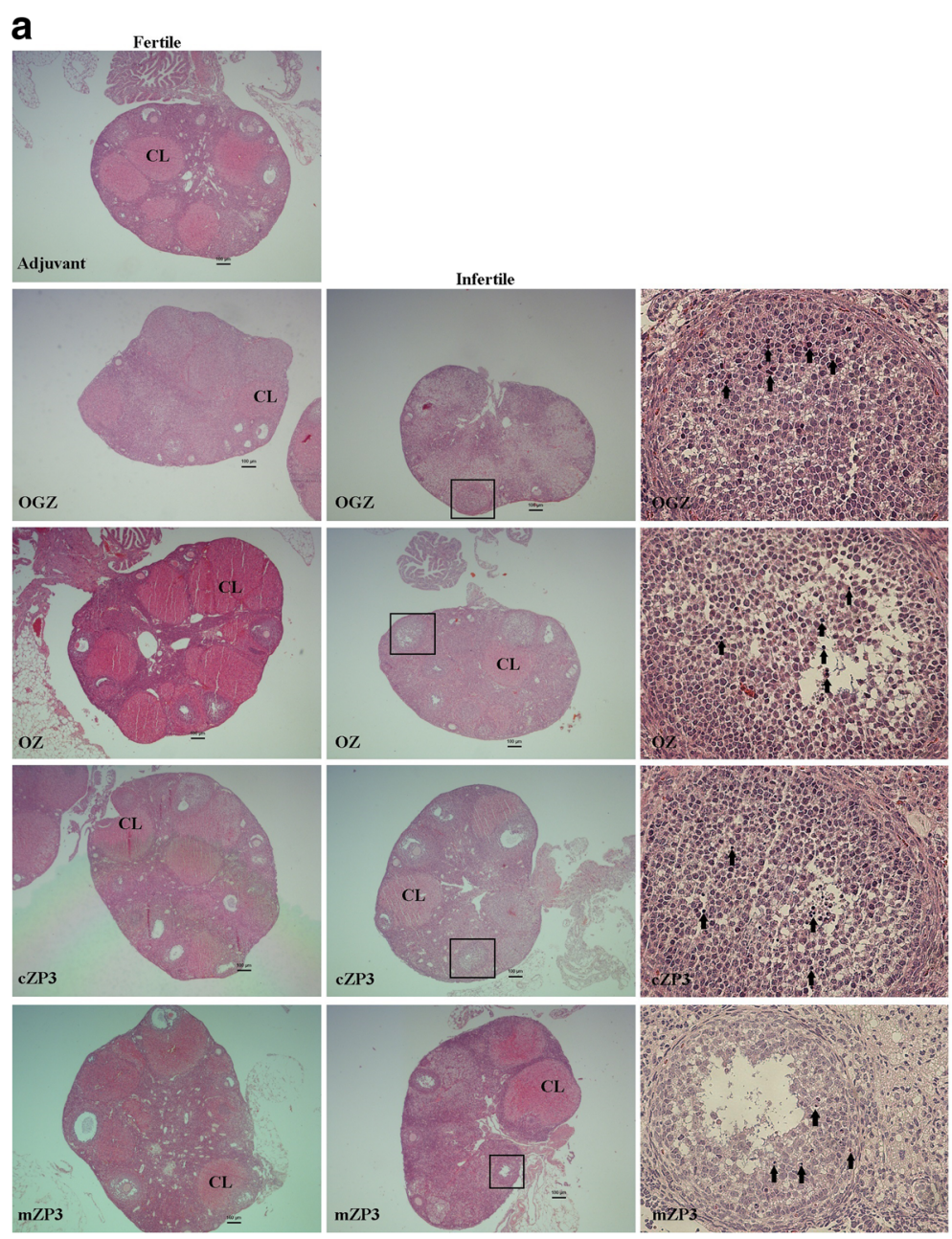

b

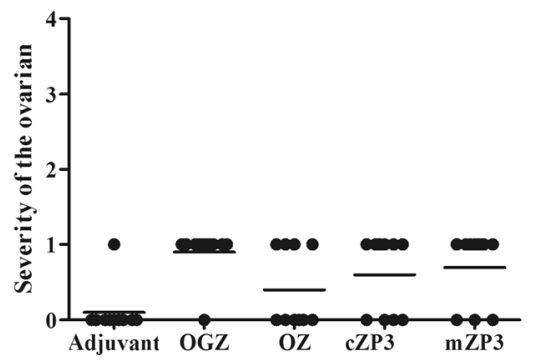

Fig. 6 Histological analysis of the ovaries of the mice immunized with different ZP3 vaccines. Mice ovaries were collected on day 210 after the first immunization. The paraffin sections were observed after HE staining. a. Histological analysis of the ovaries of the fertile and infertile mice in each group. The magnified(200x)image of the black box are on the right. Black arrows indicate inflammatory cell infiltration. CL represents corpus luteum. b. Severity of the ovarian lesions in different immunized groups

reduction in FSH and E2 concentration [21-27]. Lower concentration of FSH and E2 possibly resulted in ovary dysfunction and infertility.

The results of the indirect immunofluorescence assay showed that the Abs against cZP3 had the affinity to ZP matrix of mice and dogs. This may be attribute to the sequence similarity of cZP3 and mZP3, they shared $65 \%$ identity [28].
A large body of evidence indicates that ZP3 induces infertility via two mechanisms: (1) sufficient anti-ZP3 Abs bind to ZP matrix and block the sperm-egg interactions; (2) ovarian dysfunction mediated by inflammatory cell infiltration and anti-ZP3 Abs [29-34]. In this study, most of the infertile mice showed aberrant development of ovarian follicles, which had inflammatory cell infiltration and lack of mature follicles (Fig. 6a). The normal ovarian 
functions were interfered with Abs against ZP3 and/or inflammatory cells, which might lead to infertility. Our results agreed with this explanation.

Other studies report that ovaries receiving GnRH present a decrease in the number of corpora lutea in the infertile mice, and that lead to follicular dysplasia [24, 35-37]. Our results in OGZ group were in accord with those studies. The decrease in the number of corpora lutea and mature follicles was consistent with the decreases in sera FSH and E2 concentrations in the OGZ immunization group. These findings indicate that the Abs against cZP3 and GnRH worked together to lead to serious infertility with only $10 \%$ fertility rate and an average of 0.4 litter size in the OGZ group.

\section{Conclusions}

The results in this study showed that fusion protein OGZ had very stronger effect on reducing the fertility rate and litter size of the immunized mice than cZP3 and mZP3 by inducing high Abs levels of anti-ZP3 Abs and anti-GnRH Abs which not only blocked ZP3 but also blocked GnRH. OGZ immunization also caused pathological changes in ovary, which led to ovarian dysfunction and further increased infertility. Thus, the fusion protein OGZ could be a promising candidate for developing contraceptive vaccines for stray dogs controlling.

\section{Acknowledgements}

We would like to thank Prof Ji Ma for her assistance in statistical analysis.

\section{Availability of data and materia}

The datasets during and/or analyzed during the current study available from the corresponding author on reasonable request.

\section{Funding}

The study was financially supported by grant from the Science and Technology projects aid to Xinjiang (No. 201591134). The funders had no role in study design, data collection and analysis, decision to publish and preparation of the manuscript.

\section{Authors' contributions}

YW and YJL designed this study. YW and BBZ performed the laboratory work. YW did the data analysis. YW and FCZ drafted and revised the manuscript. All authors have read and approved the final manuscript.

\section{Ethics approval and consent to participate}

All animal experiments used in this study were approved by the Animal Ethics Committee of Xinjiang University and were conducted strictly according to University guidelines.

\section{Competing interests}

The authors declare that they have no competing interests.

\section{Publisher's Note}

Springer Nature remains neutral with regard to jurisdictional claims in published maps and institutional affiliations.
Received: 10 November 2017 Accepted: 26 April 2018

Published online: 11 May 2018

\section{References}

1. Bansal P, Chakrabarti K, Gupta SK. Functional activity of human ZP3 primary sperm receptor resides toward its C- terminus. Biol Reprod. 2009;81(1):7-15.

2. Bleil JD, Wassarman PM. Mammalian sperm-egg interaction: indentification of a glycoprotein in mouse egg zonae pellucidae possedding receptor activity for sperm. Cell. 1980;20(3):873-82.

3. Hinsch E, Aires VA, Hedrich F, Oehninger S, Hinsch KD. A synthetic decapeptide from a conserved ZP3 protein domain induces the $\mathrm{G}$ protein-regulated acrosme reaction in bovine spermatozona. Theriogenology. 2005;63(6):1682-94.

4. Jungnickel MK, Sutton KA, Wang Y, Florman HM. Phosphoinositede-dependent pathways in mouse sperm are regulated by egg ZP3 and drive the acrosome reaction. Dev Biol. 2007:304(1):116-26.

5. Yu MF, Fand WN, Xiong GF, Yang Y, Peng JP. Evidence for the inhibition in vitro by anti-ZP3 antisera derived from DNA vaccine. Vaccine. 2011;29(31): 4933-9.

6. Zhang A, Li J, Zhao G, et al. Intranasal co-administration with the mouse zona pellucida 3 ecpressing construct and its coding protein induces contraception in mice. Vaccine. 2011;29(39):6785-92.

7. Li J, Jin H, Zhang A, Li Y, Wang B, Zhang F. Enhanced contraceptive response by co-immunization of DNA and protein vaccines encoding the mouse zona pellucida 3 with minimal oophoritis in mouse ovary. J Gene Med. 2007;9(12):1095-103.

8. Kitchener AL, Kay DJ, Walters B, et al. The immune response and fertility of koalas (Phascolarctos cinereus) immunised with procine zonae pellucidae or recombinant brushtail possum ZP3 protein. J Reprod Immunol. 2009;82(1):40-7.

9. Kitchener AL, Harman A, Kay DJ, McCartney CA, Mate KE, Rodger JC. Immunocontraception of eastern Grey kangaroos (Macropus giganteus) with recombinant brushtail possum (Trichosurus vulpecula) ZP3 protein. J Reprod Immunol. 2009;79(2):156-62.

10. Mackenzie SM, McLaughlin EA, Perkins HD, et al. Immunocontraceptive effects on female rabbits infected with recombinant myxoma virus expressing rabbit ZP2 or ZP3. Biol Reprod. 2006;74(3):511-21.

11. Srivastave N, Santhanam R, Sheela P, et al. Evaluation of the immunocontraceptive potential of Escherichia coli-expressed recombinant dog ZP2 and ZP3 in a homologous animal model. Reproduction. 2002; 123(6):847-57.

12. Goodwin D, Simerska $P$, Chang $C$, et al. Active immunization of mice with $\mathrm{GnRH}$ lipopetide vaccine candidates: importance of $\mathrm{T}$ helper or multi-dimer GnRH epitope. Bioorg Med Chem. 2014;22(17):4848-54.

13. Robbins SC, Jelinski MD, Stotish RL. Assessment of the immunological efficacy of two differntnt doses of recombinant GnRH vaccine in domestic male and female cats (Felis catus). J Reprod Immunol. 2004;64(1-2):107-19.

14. Levy JK, Miller LA, Cynda Crawford P, Ritchey JW, Ross MK, Fagerstone KA $\mathrm{GnRH}$ immnocontraception of male cats. Theriogenology. 2004;62(6):1116-30.

15. Miller LA, Gionfriddo JP, Fagerstone KA, Rhyan JC, Killian GJ. The sigle-shot $\mathrm{GnRH}$ immunocontraceptive vaccine (GonaCon) in white-tailed deer: comparison of several GnRH preparations. Am J Repord Immunol. 2008; 60(3):214-23.

16. Brunius C, Zamaratskaia G, Andersson K, et al. Early immunocastration of male pigs with Improvac ${ }^{\circledR}$-effect on boar taint, hormones and reproductive organs. Vaccine. 2011;29(51):9514-20

17. Levy JK, Friary JA, Miller LA, Tucker SJ, Fagerstone KA. Long-term fertility control in female cats with GonaCon ${ }^{\mathrm{TM}}$, a GnRH immunocontraceptive. Theriogenology. 2011;76(8):1517-25.

18. Chambers RS, Johnston SA. High-level generation of polyclonal antibodies by genetic immunization. Nat Biotechnol. 2003:21(9):1088-92.

19. Tung K, Agersborg S, Bagavant H, Garza K, Wei K. Autoimmune ovarian disease induced by immunization with zona pellucida (ZP3) peptide. Curr Protoc Immunol. 2002; Chapter 15: Unit 15.17

20. Shrestha A, Wadhwa N, Gupta SK. Evaluation of recombinant fusion protein comprising dog zona pellucida glycoprotein-3 and Izumo and individual fragments as immunogens for contraception. Vaccine. 2014;32(5):564-71.

21. Arukha AP, Minhas V, Shrestha A, Gupta SK. Contraceptive efficacy of recombinant fusion protein comprising zona pellucida glycoprotein-3 fragment and gonadotropin releasing hormone. J Rrpord Immunol. 2016; 114:18-26.

22. Minhas V, Shrestha A, Wadhwa N, Singh R, Gupta SK. Novel sperm and gonadotropin-releasing hormone-based recombinant fusion protein: 
achievement of 100\% contraceptive efficacy by co-immunization of male and female mice. Mol Reprod Dev. 2016;83(12):1048-59.

23. Bauer A, Lacorn M, Danowski K, Claus R. Effects of immunization against GnRH on gonadotropins, the GH-IGF-l-axis and metabolic parameters in barrows. Animal. 2008;2(8):1215-22.

24. Robbins SC, Jelinski MD, Stotish RL. Assessment of the immunological and biological efficacy of two different doses of a recombinant $\mathrm{GnRH}$ vaccine in domestic male and female cats (Felis catus). J Reprod Immunol. 2004;64(12):107-19.

25. Dalin AM, Andresen O, Malgren L. Immunization against gnRH in mature mares: antibody titers, ovarian function, hormonal levels and oestrous behavior. J Vet Med A Physiol Pathol Clin Med. 2002;49(3):125-31.

26. Bishop DK, Wettemann RP, Yelich JV, Spicer LJ. Ovarian response after gonadotropin treatment of heifers immunized against gonadotropinreleasing hormone. J Anim Sci. 1996;74(5):1092-7.

27. Liu Y, Tian Y, Zhao X, et al. Immunization of dogs with recombinant GnRH-1 suppresses the development of reproductive function. Theriogenology. 2015;83(3):314-9

28. Gupta N, Shrestha A, Panda AK, Gupta SK. Production of tag-free recombinant fusion protein encompassing promiscuous T cell epitope of tetanus toxoid and dog zona pellucida glycoprotein-3 for contraceptive vaccine development. Mol Biotechnol. 2013;54(3):853-62.

29. Henderson CJ, Braude P, Aitken RJ. Polyclonal antibodies to a 32-kDa deglycosylated polypeptide from porcine zonae pellucidae will prevent human gamete interaction in vitro. Gamete Res. 1987;18(3):251-65.

30. Henderson CJ, Hulme MJ, Aitken RJ. Contraceptive potential of antibodies to the zona pellucida. J Reprod Fertil. 1988;83(1):325-43.

31. Henderson CJ, Hulme MJ, Aitken RJ. Analysis of the biological properties of antibodies raised against intact and deglycosylated porcine zonea pellucidae. Gamete Res. 1987;16(4):323-41.

32. Lloyd ML, Papadimitriou Jm, O'Leary S, Robertson SA, Shellam GR. Immunoglobulin to zona pellucida 3 mediates ovarian damage and infertility after contraceptive vaccination in mice. JAutoimmun 2010; 35(1): 77-85.

33. Li J, Jin H, Zhang F, et al. Treatment of autoimmune ovarian disease by co-administration with mouse zona pellucida protein 3 and DNA vaccine through induction of adaptive regulatory T cells. J Gene Med. 2008;10(7): 810-20.

34. Monnier-Barbarino P, Forges T, Faure GC, Béné MC. Ovarian autoimmunity and ovarian pathologies: antigenic targets and diagnostic significance. J Gynecol Obstet Biol Reprod (Paris). 2005;34(7 Pt 1):649-57.

35. McNeilly AS, Jonassen JA, Fraser HM. Suppression of follicular development after chronic LHRH immunoneutralization in the ewe. J Reprod Fertil. 1986; 76(1):481-90.

36. Jinshu X, Jingjing L, Duan $P$, et al. A synthetic gonadotropin-releasing hormone (GnRH) vaccine for control of fertility and hormone dependent diseases without any adjuvant. Vaccine. 2005;23(40):4834-43.

37. Killian G, Miller L, Rhyan J, Doten H. Immunocontraception of Florida feral swine with a single-dose GnRH vaccine. Am J Reprod Immunol. 2006;55(5): 378-84.

\section{Ready to submit your research? Choose BMC and benefit from:}

- fast, convenient online submission

- thorough peer review by experienced researchers in your field

- rapid publication on acceptance

- support for research data, including large and complex data types

- gold Open Access which fosters wider collaboration and increased citations

- maximum visibility for your research: over $100 \mathrm{M}$ website views per year

At BMC, research is always in progress.

Learn more biomedcentral.com/submissions 